\title{
水資源，環境おょび国土開発に関する 地域的国際協議会。報告
}

\author{
ーシンガポール、1972年 3 月13日〜17日—
}

\section{岩井重 久*}

\section{1. この国際協議会のいきさつ}

昭和 47 年 2 月末に，筆者は表記のような国際会議へ招 請される旨の電報を受取った．この会議はシンガポール 国の科学庁とアメリカ合衆国科学アカデミーとの共催に よるもので, シンガポール, マレーシア, インドネシ ア, タイ, 南ベトナム, フィリッピンの 6 加国から, 水 資源, 環境および開発に関する各種の専門家が一同に会 し，三つの分科会にわかれて協議会方式の 1 週間の会議 を持つあのである. 日本からのオブザーバーとして筆者 が選ばれたのは，世界保健機関 (WHO) 非常勤顧問之 して, 昭和 46 年 $7 \sim 8$ 月の 50 日間にわたる東南アジア 5 か国における環境污濁（公害）基礎調査に從事した結 果, WHO あてに提出した報告書 ${ }^{1}$ 中に，乙の種の国際 会議の必要性を強調しておいたととが一つの理由となっ ていると思われた。 またとの報告書は，近くストック ホルムで開催される国連の人間環境会議においてすリ ファーされるという公式通知を筆者は入手していた。乙 の報告書中に筆者が述べた諸事項のうちでも，WHOの 管轄地域わけの関係から，インド側に入るタイやインド ネシアの関係者は, フィリッピン側に入るマレーシャや シンガポールの関係者と, 熱带地方における環境問題に ついての交見が今までに十分行なわれていなかったので はないか．またたとえば，水質污濁専門家之水資源専門 家との間で，一つの国の中でも十分な相互認識が持たれ ていないのではないか. こうした地理的や専閒的な壁を 破った地域的な国際会議を開いて，胸㯲在開いて話合う ことが急務であるということを特に強調しておいたので ある・

前記 6 加国と共催国としてのアメリカ合衆国とから以 外に, 連合王国, フランス国, カナダ国，スウェーデン

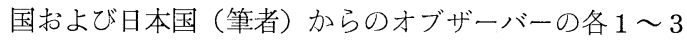
名を含め, 約50名の参加者が発表や討議に加わったが,

*京都大学教授 (衛生工学教室) 工博, 国際水質污濁研究協会 理事.

1)岩井重久：東南アジア諸国の公害事情, 水処理技術, Vol. 13、No. 1、1972
その他に多数の傍聴者があった.ここ10年来の知巳であ る Southgate 博士 (連合王国), Gomella 教授 (フラン ス), Rohlich 教授, O'Connor 教授, Okun 教授 (以上 アメリカ合衆国) 等々のほか, 昨年夏に知った東南アジ ア諸国の多くの専問家たちに再会し，意見を交わしえた ことは，筆者にとって大きい喜びであるととあに，啓発 されるとてろが多かった。

\section{2. この国際協議会のプログラム}

シンガポール会議場で開催されたこの協議会では, 初 日（13日）の午前中にシンガポール国の文部長官の L. K. San 氏の祝辞, 本協議会の議長で同国科学庁の長官 である L. K. Tatt 博士の開会の辞, およびRohlich 博 士 (ウィスコンシン大学) の講演によって開会式をおお ったが, Rohlich 博士は, 水資源と国土といった從来の この種の国際会議に, 新たに環境問題が入ってきた, い な入れざるをえなくなったことの意味と重要性とについ て強調された.

その日の午後には「水と社会的, 経済的開発」と題す る全体集会が開かれ，インドネシアの Katili 教授, タ イのCheosakul 博士, Rohlich 教授, シンガポールのK. K. Soon 氏から, それぞれの自国, あるいは国際的の事 情についての基調講演と質疑応答とが行なわれた。

第 2 日から第 4 日（16日）までは，第 1 (水資源), 第 2 (環境)，第 3 (国土開発) の三つの分科会にわかれて 協議会が催された．すなわち，各分科会でそれぞれ10〜 14編の発表論文の前刷りが参会者にあらかじめ配られて いたので, 各論文発表者による10分程度の説明ののち, それらについての活発な討議が行なわれた，発表論文は 前記の東南アジア 6 か国から提出されたものが大半を占 めたが，アメリカやヨーロッパからむ $2 ， 3$ の論文が提 出された。局地的な調査研究成果と総説的な概論とがま ざりあっていたが，いずれも相当に高い水準の内容を含 んでいた．第 1 分科会では, 地下水や水資源開発計画, 洪水調節之水保全, 下水や工場廃水の処理水の工業用水 としての再利用, 雨量の季節的変動, 石油精製工場での 
水保全，水文観測網の計画上管理のほか，アメリカ合衆 国に拈ける上・下水道を一貫した公共施設の役割りとい った題目の論文発表があった.

第 2 分科会では各国各地での河川，港湾の水質污濁防 止上の慨況や, 下水処理, 各種工場廃水処理に関する調 查研究の成果, 貯水池の富栄養化についての, とくに污 水生物学的な研究のほか, シンガポール港における重要 性加ら，船舶や石油関連工場からの油濁排水に関する処 理方式や防止法についての論文発表があった。第 3 分科 会では，石油および排煙中のイオウ含有量問題，砫肺等 の職業病問題, 都市ごみなどの固形発亲物問題のほか, 一般の環境污濁 (公害) 関係事項之, それらと関連した 住宅建設計画や都市再開発問題が論じられた。こうした 諸論文には，われわれによっても非常に参考となるもの が多いので, 希望があ机ばそのコピーをおわかちしたい と考えている.

\section{3. この国際協議会の最終全体集会において議決 された勧告事項}

第5日（17日）の最終全体集会では全貝が集まり，各 分科会ごとに採択されていた推告事項案を発表しあって 䚯議検讨した結果, 次記のような事項が議決された。原 文の英文がかならずしもよく練られていないように思わ れたので，あし諰訳があれば平に筧恕していただきた h.

\section{〔1]第 1 分科会一水資源}

(1)当分科会は大量の上水が必要量以上に浪費されてい るとと老認め, 使用水量の節約のための有効な手段の奏 施をわざして, 社会的, 衛生的見地からみた最小必要水 量に関する情報と資料とが，むっと収集されなければな らない上考える・

(2)この地域にあるほとんどの都市の上水道は, 人口の 強度の都市集中のために生じる必要水量の急激な增加に 対して追随していくことができない. 飲料水の不足は人 間の健康に関する障害を生じさせることになるので，水 に関する計画においては, 飲料水の需要に対して対応し うるようにすることがまず優先されなければならない。

(3)総合的捄よび協力的な計画性を欠くために, 直接的 で単一の目的に使用するために水資源の開発が実施され ることがきわめて多く，これがまた将来において不経済 な水資源の開発を行なわせるといった結果を生じさせて いる.したがって，水の合理的な利用のためには，あら ゆる関連分野の権威者たちの緊密な協力のもとに, 全体 計画における総合的利用がはかられなければならない. 短期的抢よび長期的の両面の開発のために，水計画を協 力させるような中央機関が，各国において設立されるこ
とが望ましい.

(4)投資額が高いわりに償却率が低いために, 地方の区 域において水道計画を補完するための資金の確保が困難 であるととを，当分科会は認めた・水系疾病の制御と減 滅, 生活水準の向上, その他水道計画がもたらす社会的 利便といった表面には現われない効果に対して，資金面 をつかさどる財政当局は，むっと注意をはらう必要があ z.

(5)水計画や水工構造物の設計を行なうにあたっては, 水文学的な資料が必要となる。もし現在において，いま だに水文学的観測網が整備されていないならば，水質や 底質の観測所之同様に, 水文学的観測縌が整備されなけ ればならない。

(6)本分科会は，乙の地域において地下水の調查之開発 とが大いに必要であり, また水理地質学者が不足してい るととを認めた，各地において，水理地質学者を訓練す るような施設が早い機会に設立されることが望まれてい る.

(7)本分科会は, 一方では水需要の急増があり, 他方で は水資源には限度があること老認めた．利用可能の水資 源が完全に開発されつくした場合，この問題を解決する ためには，使用目的に応じて水質を変えた多元給水，お よび計画的な水の再利用が注目されなければならない.

(8)水処理施没は，ますます必要以上に複雑化して如て おり，その維持管理には高度に熟練し，訓練された作業 貝在必要とする.したがって，乙の地域における水処理 施設の作業員に対して，初級から高級にいたるあらゆる 水準の訓練が必要となる.

(9)環境工学における教育と訓練との必要性が認められ る.あらゆる水準の研究と訓練とが. この地域に共通な 条件のもとに，乙の地域にある多くの施設において尖施 されなければならない.

(10)水質，水量の両面から，適切な水保全が奏施される ためには，この面における人間活動の重要性を一般人の 大多数が自筧するようにしなければならない.こうした 自覚は，教育やマスコミによって教えこまなければなら ない.

\section{〔2】第 2 分科会一環境}

(1)現在において環境污濁 (公害) が深刻な愛慮の源と なりつつある既開発国の体験を肝に銘じて，経済と国土 の開発, とくに工業と水道, 電力, 通信といった基本的 公共事業の発展のためにこの地域の諸国へ西洋風の技術 を導入するにあたって，乙の地域の諸国における生態系 を侵したり，体民の健康や福祉を損ったりするような環 境の悪化を起乙させたり, 繰返させるようなととをして はならない。 
(2)乙の地域の都市や都市域の開発を重視する場合, 安 全な水道や有効な排水の集水，処理，処分のシステムの 設置が本質的に要求され，適正であって安全な水道水を 確保し, 給水することについては異論をさしはさむ余地 はない。

(3)この地域の諸国における住民のための急增しつつあ る需要に応じるには，農業用や工業用まで含めた安全な 水の連続的な供給を確保するととを目的として，表流水 および地下水に対する污濁は防止されなければならない し，またその結果として現存の水道水源がひきつづき利 用可能となり，さらに他の水源をむ新たに開発するとと あできるということを認識すべきである.

(4)上述の諸事項を勘案して, 水資源, 環境および国土 開発に関する本地域協議会は，ここに下記のような初告 を行なうものである。

(ア)家庭用水や工業廃水のための処理規定亡放流水質基 準こが制定されなければならないが，これらの規定や基 準は実施可能なものであって，しかも放流水域のこうし た排水に対する受容量とつりあうあのでなけ机ばならな 认.

(イ)工業廃水による環境の污濁は, 工栄プラントに対し て, 放流さき水域を不当汇劣化させたり，下水道や下水 処理施設を損ったりすること无絶対に起こさせないため に, 十分なだけの発水処理施設の設置を要求し, 一体と して座業発水による環境の污濁を最低に止めさせなけれ ばならない。

(ウ)維持管理上之行政上との理由から, 分散された小規 模の施設ではなく，できるだけ一つの中央処理場で発水 処理が行なわれなければならない.

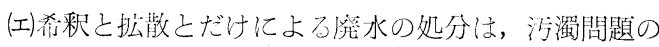
全面的解決之はならない。また有害物質を除去し，発水 に含まれる回収可能の成分を再利用するために，工業生 座工程を再検討し，改良するような日常管理が推奖され z.

(5)こじつけたり複雑ずきるような装置や機構よりも, 設計，建設执よび運転上で，もっと簡便な基準に適合さ せるために，士地上労働力とを最大限に利用するよう に, 現今における廃水処理の知識や技術が, この地域の 諸国の環境条件に対して改良され，適用されなりればな らない.

(6)油やその他の有害物質，とくに大きな障害をともな いやすい有害物質による海洋の污濁に対処するために, 非常事態が生じた場合，乙の地域の諸国における資源を 貯蔵するための運営計画を早急に樹立することと，外交 接渉や関税，入国の手続きのために地間を浪費するこ上 を避けて，人具や機械を広く準備することとが必要であ
る.

(7)下に列記するような事業在達成するために，地域的 な環境制御機関を設置することは，この地域の諸国の住 民の健康と福社とのための環境の保全に従事する技術 者, 科学者, 計画者㧍よび行政官の努力をはらいやすく し，また高揚するものである。

(イ環境制御活動におけるこの地域の諸国での研究成 果, 現場資料および経験事例を収集し, 照合し,さら に普及させるとと。

(口)科学技術の尃門家の交流

(琖員の訓練

(講習会や協議会において,アイデァや経験につい て交見するとと.

(8)既開発の諸国は，この地域内に「環境制御機関」を 実現させることをめざして，基金，職員の訓練および相 談奉仕を含めた種々の援助を与えるとと.

\section{〔3]第 3 分科会一一国土開発}

(1)公共住宅はとくに建設工業の成長老促し，未熟であ ったり，または中途半端な専門労務者のかなり多数を就 労させることができるために，乙の公共住宅の建設は経 済的開発の一つの段階であるとみなしてよい，もしこう した見解が経济学者や関連分野の専門家たちによって実 証されるのであ机ば，公共住宅の建設は大いに優先され なければならない。

(2)現存する諸問題を判定し, 解决することの必要性に 加えて, 急激な経済成長が加速され，人間の生活環境が 高揚される第 1 段階がすんでしまった後で生じるよう な, 将来に扔ける問題を予測するととの必要性がおこ 万.

(3)有効な環境制御活動老実施するためには，各国にお けるその担当責任機関に対して，政府所属の諸機関のう ちでも, 最高の権限が付与され, また最大の支持が与え られなければならない。

(4)開発のためのあらゆる努力において，社会および環 境における人間の利害がもっとも重視されなければなら ない.

(5)環境污濁 (公害) の抬大に対する一般公臬の全貝か らの注意をあっと喚起するように, 全力をあげて努力す るとと.

(6)この地域内で奏施される研究活動, 問題についての 体験と特技との交換, また，乙うした協議会によって明 らかにされるような暫定的な解決法などによって, 東南 アジア諸国に共通な環境問題の解決策が容易に見出され るであるう.したがって, 環境制御に関する近代的な施 設を備え, ぼう大な資料之深い経験とを有する地域的な 環境制御機関が，東南アジアの 1 国に早急に設置され， 
しかもこれが，乙の地域内で共通な多くの環境問題を退 治するために必須な一つの階程となることが望まれる。

(7)経済的および技術的に限度のある資源が最適化され るように, 污濁に関する諸問題は, その類型と規模とが 同定され，初級から高級にいたる明膫な優先順位がつけ られることが望ましい。

(8)環境制御をより満足なむのとするために必要なあら ゆる階程の訓練計画を，各国が樹立するととが 望まし い.

(9)人間の経済的，社会的な開発のために，人間環境の 計画，管理および制御を取扱うような実行方針の決まっ た計画を，各国の環境関係機関が策定しはじめることが 望ましい。

\section{4. この国際協議会の成果, とくに日本との関係}

筆者は主として第 2 分科会に出席したが, 種々の質問 を受けたり，討議に参加することができて大きい収獲を えた.

油濁排水問題では, 質問者が筆者が和歌山県の水質基 準（県条令）の改訂に関与していることを知っていて, 種々のこうした日本における油分に関する水質基準問題 や含油廃水处理実績について説明を求好し，筆者は筆 者なりに関連した研究上での経験や意見を述べた。

South-gate 博士は，日本でのこうした廃水処理におけ る活性污泳処理の適用に興味を示しておられた。

タイ国の代表は, 衛生工学や環境工学の教育剖練につ いて, 自国の官公庁, 大学当局, 一般民衆の理解度が浅 いため，とうした教育訓練がなおざりにされ，したがっ て実効があがらないと訴えたが，乙れに対し，筆者は日
本であ過去に扔いてはまったく同様であったが，現在で は急速にその必要性と実効之が認奻られつつあるととを 説明し，歴史がすべてを解決するであ万うという説明を 行なってかっさいを拍した。すなわち昭和33年に創設さ れた京大衛生工学科が，昭和 45 年になると，環境衛生に 関する学術を授けるような，世界中の11加国の代表的な 12の大学所属科の一つとして, WHO によって指名, 紹 介される2)の栄を得るまでにいたったという経緯を簡単 に説明した。

今後はこうした協議会に, 日本からあどしどし論文発 表が行なわれるようになることを期待したい，事実，東 南アジア諸国の関連科学者や技術者たちは, 日本の関連 科学者, 技術者による研究成果や実際的な経験を非常に 知りたがっている.プラントと公害とを組合わせて，日 本からこれらの国に輸出するととはもはやできないと思 われ，こうした意味でも，われわれは風俗習慣の似たて れらの諸国の人々が，日本の二の舞いをふまないよう に，彼らに種々の関連した資料や技術を提供し，また忠 告してあげなけ机ばならないと考える.

とにかく，「東は東，西は西…」というキップリング の有名な封の䚜があるシンガポールにおいて，乙うした 国際協議会が開催されたととは意義梁く，またこれによ って多大の収獲があったことは大いに慶賀されなければ ならない。

2) J. Cassel. et al : The education and training of engineers for environmental health (WHO Monograph Series), pp. 122 125, WHO(1970) 